\title{
Gill histopathology and micronucleus test of Astyanax jacuhiensis (Cope, 1894) (Teleostei, Characidae) to evaluate effects caused by acute exposure to aluminum
}

\author{
Thaís Dalzochio ${ }^{1 *}$ \\ Angélica Goldoni ${ }^{1}$ \\ Gabriela Zimmermann Prado Rodrigues ${ }^{2}$ \\ Ismael Evandro Petry ${ }^{2}$ \\ Luciano Basso da Silva ${ }^{1}$ \\ Günther Gehlen ${ }^{1}$ \\ Universidade FEEVALE \\ ${ }^{1}$ Programa de Pós-graduação em Qualidade Ambiental, \\ ${ }^{2}$ Laboratório de Histologia Comparada \\ RS 239, 2755, CEP 93352-000, Novo Hamburgo - RS, Brazil \\ * Autor para correspondência \\ tdalzochio@gmail.com
}

Submetido em 08/04 2015

Aceito para publicação em 15/10/2015

\section{Resumo}

Histopatologia de brânquias e teste de micronúcleos em Astyanax jacuhiensis (Cope, 1894) (Teleostei, Characidae) na avaliação dos efeitos causados pela exposição aguda ao alumínio. A contaminação de ecossistemas aquáticos por alumínio $(\mathrm{Al})$ é geralmente ocasionada por várias atividades antropogênicas. Diversas alterações morfológicas, fisiológicas e bioquímicas observadas em organismos aquáticos podem ser atribuídas à exposição ao Al. Neste contexto, o objetivo desse estudo foi investigar os efeitos da exposição aguda de peixes da espécie Astyanax jacuhiensis a diferentes concentrações de $\mathrm{Al}$ através da histologia de brânquias e frequência de micronúcleos $(\mathrm{MN})$ e anormalidades nucleares ( $\mathrm{AN}$ ) em eritrócitos. Os animais foram expostos às concentrações subletais de $0.3 \mathrm{mg} / \mathrm{L}$ e $30 \mathrm{mg} / \mathrm{L}$ de alumínio em $\mathrm{pH}$ neutro por $72 \mathrm{~h}$. Um grupo controle foi mantido em água filtrada. As alterações branquiais foram caracterizadas por hiperplasia e hipertrofia de células epiteliais, fusão lamelar, edema, descolamento epitelial, aneurisma e necrose. Um aumento significativo $(p<0.05)$ foi observado na frequência de lamelas alteradas nos grupos expostos às duas concentrações de $\mathrm{Al} \mathrm{em} \mathrm{comparação} \mathrm{aos} \mathrm{animais}$ controle. No entanto, não foram observadas diferenças significativas nas frequências de $\mathrm{MN}$ e $\mathrm{AN}$. Embora não tenham sido encontradas evidências de genotoxicidade, os resultados encontrados na análise morfológica sugerem que o $\mathrm{Al}$ foi tóxico para os peixes nas duas concentrações testadas em $\mathrm{pH}$ neutro.

Palavras-chave: Alumínio; Astyanax jacuhiensis; Brânquias; Micronúcleo

\section{Abstract}

The contamination of aquatic environments by aluminum (Al) is usually caused by several anthropogenic activities. Diverse morphological, physiological and biochemical alterations in aquatic organisms have been 
attributed to exposure to Al. In this context, the aim of this study was to investigate the effects of acute exposure to different concentrations of $\mathrm{Al}$ on the histology of gills and frequency of micronucleus (MN) and nuclear abnormalities (NA) in erythrocytes of the fish Astyanax jacuhiensis. Fish were exposed to sublethal concentrations of $0.3 \mathrm{mg} / \mathrm{L}$ and $30 \mathrm{mg} / \mathrm{L}$ of aluminum at neutral $\mathrm{pH}$ for $72 \mathrm{~h}$. A control group was kept in filtered water. The alterations in the gills were characterized by epithelial hyperplasia and hypertrophy, lamellar fusion, edema, epithelial lifting, aneurism and necrosis. A significant increase $(p<0.05)$ in the frequency of abnormal lamellae was observed in groups exposed to both concentrations of $\mathrm{Al}$ in comparison with the control group. On the other hand, no statistical differences were observed in the frequencies of MN and NA. Although no evidence of genotoxicity was observed, the results found in the gill morphological analysis suggest that $\mathrm{Al}$ was toxic to the fish at both concentrations tested under neutral $\mathrm{pH}$.

Key words: Aluminum; Astyanax jacuhiensis; Gills; Micronucleus

\section{Introduction}

Pollution, loss of biodiversity and habitat destruction are probably the main environmental threats to aquatic ecosystems (LINDE-ARIAS et al., 2008). Increases in the number and amount of industrial, agricultural and commercial chemicals discharged into aquatic environments have led to various deleterious effects on aquatic organisms (MCGLASHAN; HUGHIES, 2001; OHE et al., 2004). Contamination of water resources by metals has caused various morphological, physiological and biochemical alterations in aquatic organisms (BORDAJANDI et al., 2003; SIRAJ BASHA; USHA RANI, 2003; DAUTREMEPUITS et al., 2004).

Aluminum (Al) is a harmful metal to aquatic ecosystems, and is responsible for events of toxicity with serious ecological consequences. No normal physiological functions in biological systems are attributed to this metal (NAYAK, 2002). High concentrations of Al in aquatic ecosystems might be attributed to rock and soil erosion and also to diverse anthropogenic activities, such as water treatment and lixiviation due to mining operations and industrial landfills (KOVACEVIC et al., 2009; GARCÍA-MEDINA et al., 2011; FERNÁNDEZDÁVILA et al., 2012). Previous studies have shown that $\mathrm{Al}$ toxicity is mainly associated to low water temperature and low pH (VOURINEN et al., 1990; 1991; PÓLEO et al., 1991; ALSTAD et al., 2005; CORREIA et al., 2010). Nevertheless, concentrations higher than permissive values established by the Brazilian legislation for $\mathrm{Al}$ (between 0.1 and $0.2 \mathrm{mg} / \mathrm{L}$ ) have been observed in water resources where the $\mathrm{pH}$ is neutral (CAMARGO et al., 2009; BLUME et al., 2010). Thus, the evaluation of effects of $\mathrm{Al}$ at a neutral $\mathrm{pH}$ is important to better understand the toxic potential of this metal on living organisms.

Several biomarkers in fish have been used in field and laboratory studies to assess the effects of contaminants. Fish gills are particularly sensitive to water quality, constituting the first target of pollutants, due to their anatomic location, direct contact with the water and quick absorption (PANDEY et al., 2008). Alterations in gill epithelium are a consequence of exposure to contaminants, with the severity of alterations depending on the pollutant concentration and exposure period (SANTOS et al., 2012). Thus, the histopathological analysis of gills represents a reliable tool for evaluating the effects of pollutants, such as metals, in fish. Another tool often used to investigate the potential effects of environmental pollutants in these organisms is the micronucleus (MN) test. Micronuclei can originate both from acentric fragments resulting from chromosomal breaks and from whole chromosomes delayed, which are not incorporated into the main nucleus during cellular division. These characteristics allow the detection of damage provoked both by clastogenic and aneugenic chemicals (UDROIU, 2006). This analysis has been used in different environmental assessment studies to detect genotoxic effects of pure chemicals or mixtures of chemicals (ÇAVAS; ERGENE-GÖZÜKARA, 2005; LEMOS et al., 2007). The concomitant analysis of the occurrence of erythrocyte nuclear abnormalities (NA) allows for the evaluation of another toxicity biomarker, which has been successfully applied under field and laboratory conditions (PACHECO; SANTOS, 1998; ÇAVAS; KÖNEN, 2008; OMAR et al., 2012). 
Therefore, the present work studied the effects of exposure to different concentrations of $\mathrm{Al}$ on the histology of gills and MN and NA in the erythrocytes of a Characidae fish species (Astyanax jacuhiensis, common name lambari) after acute exposure at neutral $\mathrm{pH}$.

\section{Material and Methods}

\section{Specimen procurement and acclimation}

Specimens of $A$. jacuhiensis ( $\pm 5 \mathrm{~cm}$ in length) were obtained from a local fish farm, transported to the laboratory, subjected to a 7-day acclimation period under a natural photoperiod at $22 \pm 1^{\circ} \mathrm{C}$, and fed with fish food every three days. The fish were maintained in oxygenated filtered water (filtration using sequential purification with activated charcoal, resin of ion exchange, followed by reverse osmosis, reaching parameters for drinking water). Physicochemical parameters of the filtered water were $\mathrm{pH} 7.4$, total dissolved solids $130.0 \mathrm{mg} / \mathrm{L}$, conductivity $19.31 \mu \mathrm{S} / \mathrm{cm}$, turbidity $0.1 \mathrm{NTU}$ and hardness $0.7 \mathrm{mg} \mathrm{CaCO}_{3} / \mathrm{L}$.

\section{Toxicity assays}

Aluminum toxicity was evaluated at two different concentrations, $0.3 \mathrm{mg} / \mathrm{L}$ and $30 \mathrm{mg} / \mathrm{L}$, and prepared from a stock solution of $\mathrm{AlCl}_{3}\left(\mathrm{Vetec}^{\mathbb{B}}\right.$, purity 99.99 percent) dissolved in filtered water. After the $\mathrm{Al}$ was added to the experimental media, the $\mathrm{pH}$ was measured and adjusted to 7.0 with $\mathrm{NaOH}$ (when necessary). The experimental media were left to stand for $24 \mathrm{~h}$ to allow decantation and to let the system equilibrate. The concentration $0.3 \mathrm{mg} / \mathrm{L}$ of Al was chosen due to the fact that it is the maximum level recommended for drinking water by decree No. 518/2004 of the Brazilian Ministry of Health (BRASIL, 2004). The concentration $30 \mathrm{mg} / \mathrm{L}$ of Al has been previously found in Sinos River, in southern Brazil (BLUME et al., 2010), and was chosen to evaluate the possible toxic effects induced by an environmentally relevant concentration of Al.

After the acclimation period, fish were randomly divided into three groups, control $(\mathrm{n}=10$, maintained in filtered well water), Al $0.3 \mathrm{mg} / \mathrm{L}(\mathrm{n}=10)$ and $\mathrm{Al} 30$ $\mathrm{mg} / \mathrm{L}(\mathrm{n}=10)$, and placed in 9-L aquaria under constant aeration. The $\mathrm{pH}$ was evaluated during the experiment, where no oscillation was observed.

Fish were exposed for $72 \mathrm{~h}$, and then they were anesthetized by immersion in clove oil (1\%) and killed by medullar transaction following the animal care protocols approved by the Ethics Committee for Animal Experimentation of Universidade Feevale (protocol No. 01.040.2013). The first arch of gills was removed for histology analysis and blood samples from the caudal vein were collected for the $\mathrm{MN}$ test.

\section{Gill histopathology}

After $24 \mathrm{~h}$ of fixation in $4 \%$ formaldehyde, the gills were dehydrated in a graded ethanol series and embedded in paraffin. The $5 \mu \mathrm{m}$ thick sections, made with a rotatory microtome $\left(\right.$ Leica $\left.^{\circledR}\right)$, were stained with hematoxylin-eosin (H\&E), examined with a light microscope (Olympus CX41) (400x magnification) and recorded using a CCD camera (Olympus DSC 3000). For the histopathological evaluation, an average of 10 fields per animal was analyzed, (each field contained one primary lamella with eight secondary lamellae). The observed gill alterations were epithelial hyperplasia and hypertrophy, lamellar fusion, edema, epithelial lifting, aneurism and necrosis. For each fish, the following was recorded: the frequency of lamellae with each type of alteration (sum of lamellae with that alteration divided by the total number of lamellae analyzed) and the frequency of abnormal lamellae (sum of lamellae with one or more alterations divided by the total number of lamellae analyzed).

\section{Micronucleus test}

Peripheral blood smears were obtained from a caudal section. The samples were fixed in absolute ethanol for $10 \mathrm{~min}$ and stained with 5\% Giemsa for 10 $\mathrm{min}$. The relative frequency of micronucleated cells was evaluated with a light microscope (1000x magnification) by scoring an average of 2000 erythrocytes per fish. Coded and randomized slides were scored using a blind review by a single observer. The criteria used for the identification of micronuclei followed the protocol 
according to Grisolia (2002); briefly, (a) diameter smaller than approximately $1 / 3$ of the main nucleus, (b) absence of contact with the nucleus and (c) color and texture similar to the nucleus. Other anomalies, such as invaginations, buds and binucleated cells, were recorded as nuclear abnormalities (NA).

\section{Statistical analysis}

Data are expressed as mean \pm standard deviation. For the histological analysis, mean values for the different experimental conditions were compared using one-way analysis of variance (ANOVA) followed by Tukey's test. Considering the MN and NA test, mean values were compared using the Kruskal-Wallis test. The significance level adopted was 95\% $(\mathrm{p}<0.05)$.

\section{Results}

\section{Gill histopathology}

The microscopical examination of the gills of A. jacuhiensis exposed to different Al concentrations revealed several histopathological alterations, such as hyperplasia and hypertrophy of epithelial cells, edema, aneurysm, lamellar fusion, epithelial lifting and necrosis (Figure 1). Besides these lamellar alterations, proliferation of the filament epithelium was found in groups exposed to Al, while it was absent in the control group.
The mean frequencies of secondary lamellae with each type of alteration observed in the gills of A. jacuhiensis are shown in Table 1 . The frequency of lamellae with hyperplasia of epithelial cells was significantly higher in the fish exposed to $0.3 \mathrm{mg} / \mathrm{L}$ Al than in the control group $(P<0.05)$. No statistical differences among groups were found in the frequency of lamellae with the other types of gill alterations.

TABLE 1: Frequency of lamellae with histological alterations observed in the gills of Astyanax jacuhiensis after exposure for $72 \mathrm{~h}$ to different aluminum concentrations (mean \pm standard deviation).

\begin{tabular}{lccc}
\hline \multicolumn{1}{c}{ Alteration } & Control & Al 0.3 mg/L & Al 30 mg/L \\
\hline $\begin{array}{l}\text { Hyperplasia of } \\
\text { epithelial cells }\end{array}$ & $0.16 \pm 0.8^{\mathrm{a}}$ & $0.33 \pm 0.1^{\mathrm{b}}$ & $0.22 \pm 0.11^{\mathrm{a}}$ \\
$\begin{array}{l}\text { Hypertrophy of } \\
\text { epithelial cells }\end{array}$ & $0.07 \pm 0.04^{\mathrm{a}}$ & $0.14 \pm 0.07^{\mathrm{a}}$ & $0.15 \pm 0.11^{\mathrm{a}}$ \\
Edema & $0.03 \pm 0.04^{\mathrm{a}}$ & $0.02 \pm 0.02^{\mathrm{a}}$ & $0.02 \pm 0.02^{\mathrm{a}}$ \\
Aneurysm & $0.05 \pm 0.04^{\mathrm{a}}$ & $0.06 \pm 0.04^{\mathrm{a}}$ & $0.09 \pm 0.08^{\mathrm{a}}$ \\
Lamellar fusion & $0^{\mathrm{a}}$ & $0^{\mathrm{a}}$ & $0.01 \pm 0.02^{\mathrm{a}}$ \\
Epithelial lifting & $0^{\mathrm{a}}$ & $0^{\mathrm{a}}$ & $0.03 \pm 0.05^{\mathrm{a}}$ \\
Necrosis & $0.04 \pm 0.05^{\mathrm{a}}$ & $0.09 \pm 0.15^{\mathrm{a}}$ & $0.06 \pm 0.03^{\mathrm{a}}$ \\
\hline
\end{tabular}

Different letters indicate significant difference among groups $(P<0.05)$.

Considering the different types of gill alterations together, fish exposed to both $\mathrm{Al}$ concentrations showed significantly higher frequencies of abnormal lamellae compared to the control group (Figure 2). The frequency of abnormal lamellae for the control, Al $0.3 \mathrm{mg} / \mathrm{L}$ and Al

FIGURE 1: Cross sections of gills of Astyanax jacuhiensis.
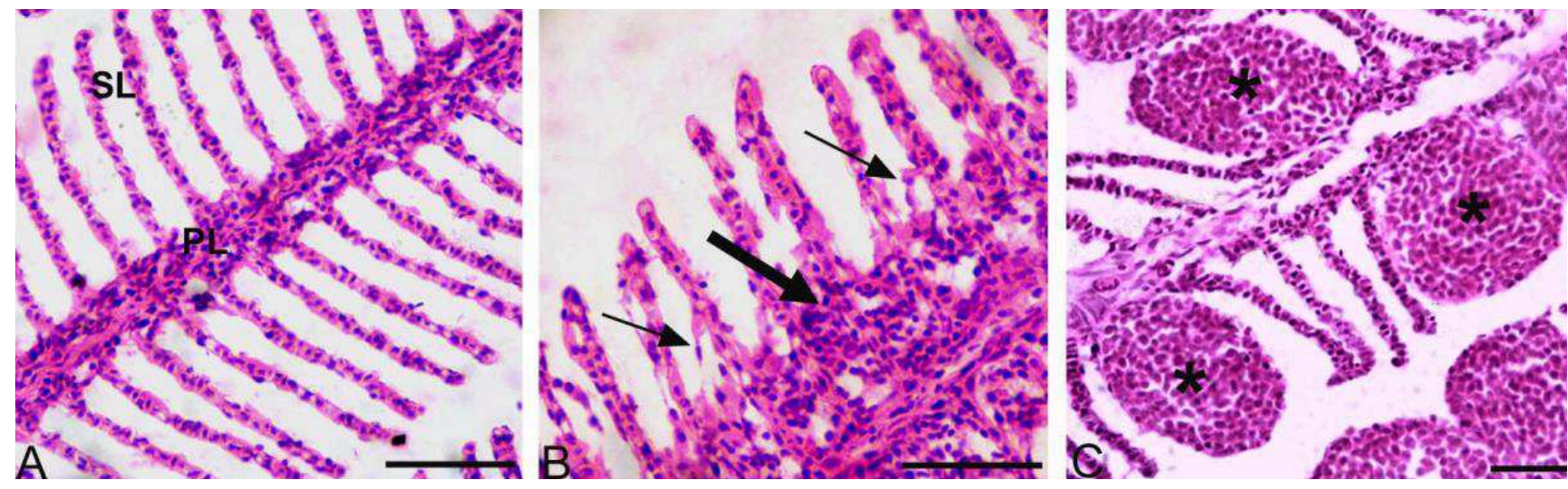

A - General view of gills, presenting primary (PL) and secondary (SL) lamellae with no alterations. B - Lamella exhibiting epithelial lifting (thin arrow) and proliferation of the filament epithelium (thick arrow). C - Aneurysms (*). Hematoxylin-eosin stain. Scale bar $=50 \mu \mathrm{m}$. 
FIGURE 2: Frequency of normal and abnormal secondary lamellae in control group and groups exposed to different aluminum concentrations.

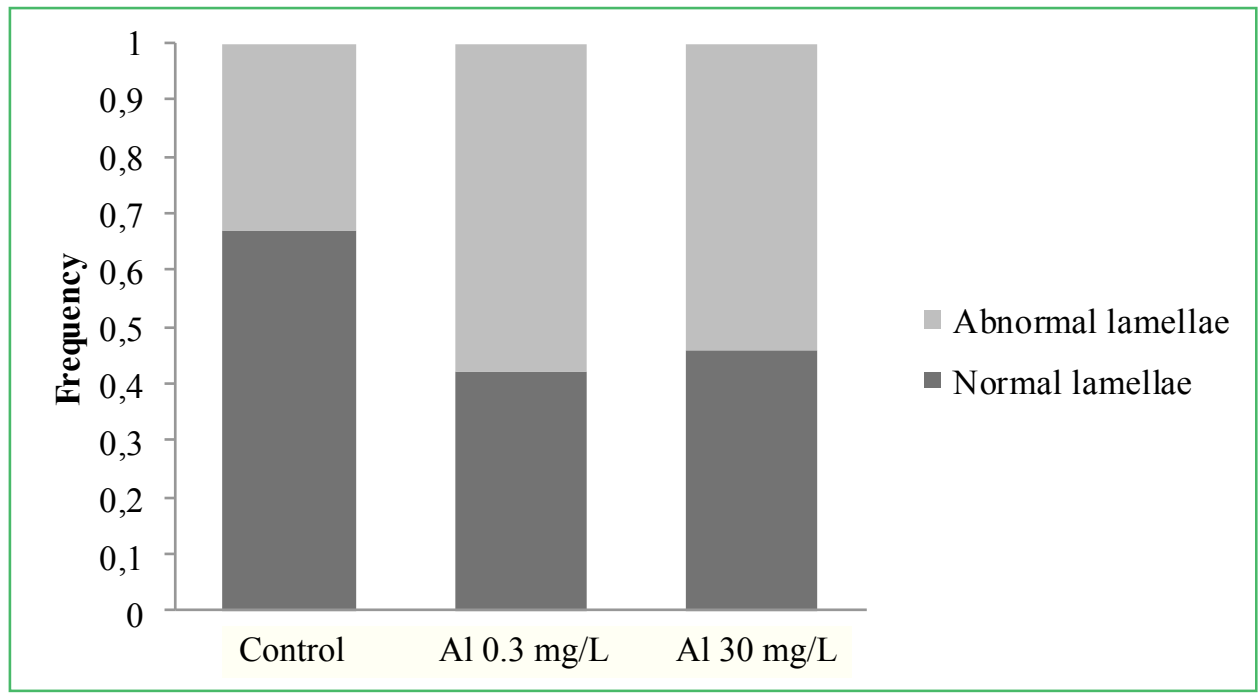

Different letters indicate that difference is statistically significant among groups $(P<0.05)$.

$30 \mathrm{mg} / \mathrm{L}$ was $0.34 \pm 0.09,0.58 \pm 0.08$ and $0.55 \pm 0.04$, respectively $(P=0.000093)$.

\section{Micronucleus test}

Table 2 shows the results for the micronucleus (MN) and nuclear abnormalities (NA) analysis in the erythrocytes of $A$. jacuhiensis after exposure to different Al concentrations and in the control group. Although fish exposed to both $\mathrm{Al}$ concentrations presented a higher mean frequency of $\mathrm{MN}$ and NA when compared to the control group, no statistical differences were observed $(P=0.19$ for $\mathrm{MN}$ and $P=0.27$ for NA).

TABLE 2: Micronuclei (MN) and nuclear abnormalities (NA) frequencies in Astyanax jacuhiensis after exposure for $72 \mathrm{~h}$ to different aluminum concentrations (mean \pm standard deviation).

\begin{tabular}{lcccc}
\hline & Control & Al $\mathbf{0 . 3} \mathbf{~ m g} / \mathbf{L}$ & Al $30 \mathbf{~ m g} / \mathbf{L}$ & $\boldsymbol{P}$ \\
\hline MN/1000 & $0.00 \pm 0.00$ & $0.15 \pm 0.24$ & $0.10 \pm 0.21$ & 0.19 \\
NA/1000 & $0.95 \pm 0.83$ & $1.70 \pm 1.16$ & $1.75 \pm 1.75$ & 0.27 \\
\hline
\end{tabular}

\section{Discussion}

According to Brazilian law, the limits for dissolved aluminum in freshwater are between 0.1 and
$0.2 \mathrm{mg} / \mathrm{L}$ (CONAMA, 2005). Nevertheless, some studies have reported much higher levels of aluminum in the environment, such as $5.7 \mathrm{mg} / \mathrm{L}$ (CAMARGO et al., 2009) and $30 \mathrm{mg} / \mathrm{L}$ (BLUME et al., 2010). Fish exposure to aluminum leads to osmoregulatory disturbances (CAMARGO et al., 2009), decrease in body weight (BRODEUR et al., 2001), alterations in swimming performance and blood chemistry (YTRESTØYL et al., 2001) and reduction of mucous cells (LEDY et al., 2003). However, most aluminum toxicity effects are known to be more intense under acidic $\mathrm{pH}$ conditions. In the present work, the occurrence of morphological alterations in gills and the frequency of micronuclei and nuclear abnormalities, in erythrocytes of $A$. jacuhiensis exposed to $\mathrm{Al}$ concentrations of $0.3 \mathrm{mg} / \mathrm{L}$ and $30 \mathrm{mg} / \mathrm{L}$, were evaluated under neutral conditions, as found in most Brazilian rivers.

\section{Gill histopathology}

Histopathological alterations in the gills of $A$. jacuhiensis have been found, which demonstrates the potential of this metal to cause changes in this organ. Among other effects, Vourinen et al. (2003) showed that $\mathrm{Al}$ accumulated inside the gill tissue of vendance (Coregonus albula) exposed to an acidic $\mathrm{pH}$ and $\mathrm{Al}$ 
(200 $\left.\mu \mathrm{g} / \mathrm{L}^{-1}\right)$, suggesting alterations in gill membrane properties. However, there is a lack of studies regarding the relationship between $\mathrm{Al}$ exposure at neutral $\mathrm{pH}$ and morphological alterations in fish gills. In the present study, a significantly higher frequency of alterations per secondary lamellae was found in both groups exposed to Al. The most prevalent alterations were hyperplasia and hypertrophy of epithelial cells. These alterations are known as a mechanism of defense because they increase the diffusion distance between the external medium and the bloodstream, acting as a barrier against the entry of the pollutant into the body (MALLATT, 1985; POLEKSIC; MITROCIC-TUTUNDZIC, 1994; FERNANDES; MAZON, 2003). A significantly higher frequency of hyperplasia of epithelial cells was observed in the $\mathrm{Al} 10.3 \mathrm{mg} / \mathrm{L}$ group in comparison with the control group; thus, a dose-response relationship was not observed. Monteiro et al. (2008) also did not observe this relationship in a study about the effects of copper exposure performed with Oreochromis niloticus.

The thickening of the filament gill epithelium observed in groups exposed to Al may be due to the proliferation of cells rich in mitochondria and stem cells (DANG et al., 1999). Along with hyperplasia and hypertrophy of epithelial cells, this effect is also considered to be a protection mechanism against toxic agents (CENGIZ; UNLU, 2002).

Other responses observed include aneurisms, epithelial lifting, necrosis and lamellar fusion. Although no significant difference was observed among the groups, the frequency of such alterations was commonly higher in the groups exposed to the Al concentrations. The aneurisms result from extended vasodilatation, with the collapse of pillar cells and the breakdown of vascular integrity (MARTINEZ et al., 2004), and have been associated with the presence of irritants in the water (PEREIRA et al., 2013). Necrosis was also more frequent in the groups exposed to both $\mathrm{Al}$ concentrations. This lesion is characterized as irreversible and occurs following exposure to toxicants (TAKASHIMA; HIBIYA, 1995). Lamellar fusion and epithelial lifting were only observed in fish exposed to $\mathrm{Al} 30 \mathrm{mg} / \mathrm{L}$. These lesions diminish the vulnerable gill surface area and are probably a defense strategy (MONTEIRO et al., 2008).
Possibly, even more severe lesions would be observed in fish after chronic exposure and/or higher aluminum concentrations.

Our histological findings are in accordance with other laboratory studies about metal exposure (GALVEZ et al., 1998; CERQUEIRA; FERNANDES, 2002; SANTOS et al., 2012) because the alterations observed appear to be a general response to most irritant agents in fish gill tissue (MALLATT, 1985). The histopathology of fish gills is considered to be an important tool in evaluating the effects of toxicant exposure, because the injuries to this organ may reduce oxygen consumption and disrupt the osmoregulatory functions of the fish (MISHRA; MOHANTY, 2008). Nevertheless, a quantitative evaluation of gill alterations is important in order to perform a thorough analysis of morphological data, as performed in our study.

\section{Micronucleus test}

In a study by Galindo et al. (2010), micronuclei frequencies did not increase significantly in Prochilodus lineatus juveniles exposed to $\mathrm{Al}$ and an acidic $\mathrm{pH}$ for 6, 24 and $96 \mathrm{~h}$, in comparison with the negative control group. However, in the same study, nuclear abnormalities frequencies increased significantly after all exposure periods. García-Medina et al. (2013), when evaluating the genotoxic effects of three $\mathrm{Al}$ concentrations ( 0.05 $\mathrm{mg} / \mathrm{L}, 120 \mathrm{mg} / \mathrm{L}$ and $239 \mathrm{mg} / \mathrm{L}$ ) on C. carpio, found a significant increase in the micronuclei frequencies after 12, 24 and $48 \mathrm{~h}$. However, after 72 and $96 \mathrm{~h}$, micronuclei frequencies decreased, suggesting that, for C. carpio, the peak induction of micronuclei caused by $\mathrm{Al}$ exposure occurs until $48 \mathrm{~h}$ and was very low.

There are no previous studies reporting the required time for the formation of micronuclei in $A$. jacuhiensis. The time required to reach a peak induction in micronuclei frequency varies among different species. Normally, micronucleated erythrocytes in fish occur 1 to 5 days after exposure, although in most fish species micronuclei are formed on days 2 and 3 (UDROIU, 2006). Considering that micronuclei can only be formed once cells undergo mitosis, detailed studies including different exposure periods are 
essential to understand the cell cycle and micronuclei induction of this species.

Several authors have suggested that variations in the shape of the nucleus could represent a manifestation of the effects of xenobiotics. Although the mechanisms underlying the formation of these abnormalities have not been fully explained, the induction of nuclear abnormalities has been reported in fish erythrocytes as a consequence of exposure to contaminants with cytotoxic, genotoxic, mutagenic or carcinogenic activity (AYLLON; GARCIA-VAZQUEZ, 2000; TALAPATRA; BANERJEE, 2007; MURANLI; GÜNER, 2011). Therefore, it has been suggested that in genotoxicity studies with fish models, the analysis of nuclear abnormalities should be considered and may complement micronuclei scoring (ÇAVAS; ERGENE GÖZÜKARA, 2005). In this study, nuclear abnormalities frequencies found in control animals and in animals exposed to both $\mathrm{Al}$ concentrations were considered low. However, our results are in accordance with several other authors, which also report a higher frequency of abnormalities in fish peripheral erythrocytes, in comparison with the micronuclei frequencies (FERRARO et al., 2004; CAVALCANTE et al., 2008; OLIVEIRA-MARTINS; GRISOLIA, 2009; MURANLI; GÜNER, 2011). Therefore, the concomitant analysis of nuclear abnormalities could represent an alternative to overcoming a possible lack of sensitivity related to the general low micronuclei frequency in fish erythrocytes (AYLLON, GARCIAVAZQUEZ, 2000; GUILHERME et al., 2008; MONTEIRO et al., 2011).

In the present study, no evidence of genotoxicity was observed, as revealed by the micronucleus and nuclear abnormalities test. However, the acute exposure of $A$. jacuhiensis to aluminum at neutral $\mathrm{pH}$ was toxic, given the histological alterations found, even at the concentration allowed by Brazil for drinking water. However, more studies that include interactions such as water temperature, $\mathrm{pH}$, and the physiology of fish species, in order to investigate the Al toxicity, are valuable and needed to improve what is known about the effects of this metal.

\section{Acknowledgements}

This work was supported in part by grants from Universidade FEEVALE, FAPERGS, RS-Brazil and CNPq.

\section{References}

ALSTAD, N. E. W.; KJELSBERG, B. M.; VOLLESTAD, L. A.; LYDERSEN, E.; POLÉO, A. B. S. The significance of water ionic strength on aluminium toxicity in brown trout (Salmo trutta L.). Environmental Pollution, Amherst, v. 133, p. 333-342, 2005.

AYLLON, F.; GARCIA-VAZQUEZ, E. Induction of micronuclei and other nuclear abnormalities in European minnow Phoxinus phoxinus and mollie Poecilia latipinna: an assessment of the fish micronucleus test. Mutation Research, Amsterdam, v. 467, p. $177-$ $186,2000$.

BLUME, K. K.; MACEDO, J. C.; MENEGUZZI, A.; SILVA, L. B.; QUEVEDO, D. M.; RODRIGUES, M. A. Water quality assessment of the Sinos River, Southern Brazil. Brazilian Journal of Biology, São Carlos, v. 70, p. 1185-1193, 2010.

BORDAJANDI, L. R.; GÓMEZ, G.; FERNÁNDEZ, M. A.; ABAD, E.; RIVERA, J.; GONZÁLEZ, M. J. Study on PCBs, $\mathrm{PCDD} / \mathrm{Fs}$, organochlorine pesticides, heavy metals and arsenic content in freshwater fish species from the River Turia (Spain). Chemosphere, Elmsford, v. 53, n. 2, p. 163-171, 2003.

BRASIL - MINISTÉRIO DA SAÚDE. Establishes procedures and responsabilities related to the control and vigilance of quality water for human supply and its pattern of potability, and others. Portaria n. 518, de 25 de março de 2004. Lex. Legislação federal e marginália. Disponível em: <http://dtr2001.saude.gov. br/sas/PORTARIAS/Port2004/GM/GM-518.htm>. Acesso em: 19 mar. 2014.

BRODEUR, C.; OKLAND, F.; FINSTAD, B.; DIXON, D. G.; MCKINLEY, R. S. Effects of subchronic exposure to aluminium in acidic water on bioenergetics of atlantic salmon (Salmo salar). Ecotoxicology and Environmental Safety, Amsterdam, v. 49, p. 226-234, 2001

CAMARGO, M. M.; FERNANDES, M. N.; MARTINEZ, C. B. R. How aluminium exposure promotes osmoregulatory disturbances in the neotropical freshwater fish Prochilodus lineatus. Aquatic Toxicology, Amsterdam, v. 94, n. 1, p. 40-46, 2009.

CAVALCANTE, D. G. S. M.; MARTINEZ, C. B. R.; SOFIA, S. H. Genotoxic effects of Roundup on the fish Prochilodus lineatus. Mutation Research, Amsterdam, v. 655, p. 41-46, 2008.

CENGIZ, E. I.; UNLU, E. Histopathological changes in the gills of mosquito fish Gambusia affinis exposed to endosulfan. Bulletin of Environmental Contamination and Toxicology, New York, v. 68, n. 2, p. 290-296, 2002.

CERQUEIRA, C. C. C.; FERNANDES, M. N. Gill tissue recovery after copper exposure and blood parameter responses in the tropical fish Prochilodus scrofa. Ecotoxicology and Environmental Safety, Amsterdam, v. 52, n. 2, p. 83-91, 2002.

CONAMA - CONSELHO NACIONAL DO MEIO AMBIENTE/ MINISTÉRIO DO MEIO AMBIENTE. Resolução nº 357 de 17 
de marco de 2005. Disponível em: <http://www.mma.gov.br/port/ conama/legiano1.cfm?codlegitipo $=3 \&$ ano $=2005>$. Acesso em: 19 mar. 2014.

CORREIA, T. G.; NARCIZO, A. M.; BIANCHINI, A.; MOREIRA, R. G. Aluminum as an endocrine disruptor in female Nile tilápia (Oreochromis niloticus). Comparative Biochemistry and Physiology, Salt Lake City, v. 151, p. 461-466, 2010.

ÇAVAS, T.; ERGENE-GÖZÜKARA, S. Induction of micronuclei and nuclear abnormalities in Oreochromis niloticus following exposure to petroleum refinery and chromium processing plant effluents. Aquatic Toxicology, Amsterdam, v. 74, n. 3, p. 264-271, 2005.

ÇAVAS, T.; KÖNEN, S. In vivo genotoxicity testing of the amnesic shellfish poison (domoic acid) in piscine erythrocytes using the micronucleus test and the comet assay. Aquatic Toxicology, Amsterdam, v. 90, p. 154-159, 2008.

DANG, Z.; LOCK, R. A. C.; FLIK, G.; WENDELAAR BONGA, S. E. Metalliothionein response in gills of Oreochromis mossambicus exposed to copper in fresh water. The American Journal of Physiology, Bethesda, v. 277, p. R320-331, 1999.

DAUTREMEPUITS, C.; PARIS-PALACIOS, S.; BETOULLE, S.; VERNET, G. Modulation in hepatic and head kidney parameters of carp (Cyprinus carpio L.) induced by copper and chitosan. Comparative Biochemistry and Physiology, Salt Lake City, v. 137, n. 4, p. 325-333, 2004

FERNANDES, M. N.; MAZON, A. F. Environmental pollution and fish gill morphology. In: VAL, A. L.; KAPOOR, B. G. (Ed.). Fish adaptations. Enfield: Enfield Science Publishers, 2003. p. 203-231. FERNÁNDEZ-DÁVILA， M. L.; RAZO-ESTRADA， A. C.; GARCÍA-MEDINA， S.; GÓMEZ-OLIVÁN, L. M.; PIÑÓNLÓPEZ, M. J.; IBARRA, R. G.; GALAR-MARTÍNEZ, M. Aluminum-induced oxidative stress and neurotoxicity in grass carp (Cyprinidae- Ctenopharingodon idella). Ecotoxicology and Environmental Safety, Amsterdam, v. 76, n. 2, p. 87-92, 2012.

FERRARO, M. V. M.; FENOCCHIO, A. S.; MANTOVANI, M. S.; RIBEIRO, C. O.; CESTARI, M. M. Mutagenic effects of tributyltin and inorganic lead ( $\mathrm{Pb}$ II) on the fish H. malabaricus as evaluated using the comet assay and the piscine micronucleus and chromosome aberration tests. Genetics and Molecular Biology, Ribeirão Preto, v. 27, p. 103-107, 2004.

GALINDO, B. A.; TROILO, G.; CÓLUS, I. M. S.; MARTINEZ, C. B. R.; SOFIA, S. H. Genotoxic effects of aluminium on the neotropical fish Prochilodus lineatus. Water, Air, and Soil Pollution, Dordrecht, v. 212, p. 419-428, 2010.

GALVEZ, F.; WEBB, N.; HOGSTRAND, C.; WOOD, C. M. Zinc binding to the gills of rainbow trout: the effect of long-term exposure to sublethal zinc. Journal of Fish Biology, Malden, v. 52, p. 1089-1104, 1998.

GARCÍA-MEDINA, S.; NÚÑEZ-BETANCOURT, J. A.; GARCÍAMEDINA, A. L.; GALAR-MARTÍNEZ, M.; NERI-CRUZ, N.; ISLAS-FLORES, H.; GÓMEZ-OLIVÁN, L. M. The relationship of cytotoxic and genotoxic damage with blood aluminum levels and oxidative stress induced by this metal in common carp (Cyprinus carpio). Ecotoxicology and Environmental Safety, Amsterdam, v. 96, p. 191-197, 2013.

GARCÍA-MEDINA，S.; RAZO-ESTRADA，A. C.; GALARMARTÍNEZ, M.; CORTÉZ-BARBERENA, E.; GÓMEZ-
OLIVÁN, L. M.; ÁLVAREZ-GONZÁLEZ, I.; MADRIGALBUJAIDAR, E. Genotoxic and cytotoxic effects induced by aluminum in the lymphocytes of the common carp (Cyprinus carpio). Comparative Biochemistry and Physiology, Salt Lake City, v. 153, n. 1, p. 113-118, 2011.

GRISOLIA, C. K. A comparison between mouse and fish micronucleus test using cyclophosphamide, mitomycin $\mathrm{C}$ and various pesticides. Mutation Research, Amsterdam, v. 518, n. 2, p. $145-150,2002$

GUILHERME, S.; VÁlEGA, M.; PEREIRA, M. E.; SANTOS, M. A.; PACHECO, M. Erythrocytic nuclear abnormalities in wild and caged fish (Liza aurata) along an environmental mercury contamination gradient. Ecotoxicology and Environmental Safety, Amsterdam, v. 70, n. 3, p. 411-421, 2008.

KOVACEVIC, G.; GREGOROVIC, G.; KALAFATIC, M.; JAKLINOVIC, I. The effect of aluminium on the planarian Polycelis feline (Daly). Water, Air, and Soil Pollution, Dordrecht, v. 196 , p. 333-344, 2009

LEDY, K.; GIAMBÉRINI, L.; PIHAN, J. C. Mucous cell responses in gill and skin of brown trout Salto trutta fario in acidic, aluminium-containing stream water. Diseases of Aquatic Organisms, Oldendorf, v. 56, p. 235-240, 2003.

LEMOS, C. T.; RÖEDEL, P. M.; TERRA, N. R.; OLIVEIRA, N. C. D.; ERDTMANN, B. River water genotoxicity evaluation using micronucleus assay in fish erythrocytes. Ecotoxicology and Environmental Safety, Amsterdam, v. 66, p. 391-401, 2007.

LINDE-ARIAS, A. R.; INÁCIO, A. F.; ALBURQUERQUE, C.; FREIRE, M. M.; MOREIRA, J. C. Biomarkers in an invasive fish species, Oreochromis niloticus, to assess the effects of pollution in a highly degraded Brazilian River. Science of the Total Environment, Amsterdam, v. 399, p. 186-192, 2008.

MALLATT, J. Fish gill structural changes induced by toxicants and other irritants: a statistical review. Canadian Journal of Fisheries and Aquatic Sciences, Ottawa, v. 42, p. 630-648, 1985.

MARTINEZ, C. B. R.; NAGAE, Y.; ZAIA, T. B. V.; ZAIA, D. A. M. Morphological and physiological acute effects lead in the neotropical fish Prochilodus lineatus. Brazilian Journal of Biology, São Carlos, v. 64, n. 4, p. 797-807, 2004.

MCGLASHAN, D. J.; HUGHIES, J. M. Genetic evidence for historical continuity between populations of the Australian freshwater fish Craterocephalus stercusmuscarum (Atherinidae) east and west of the Great Diving Range. Journal of Fish Biology, Malden, v. 59, p. 55-67, 2001.

MISHRA, A. K.; MOHANTY, B. Acute toxicity impacts of hexavalent chromium on behavior and histopathology of gill, kidney and liver of the freshwater fish, Channa punctatus (Bloch). Environmental Toxicology Pharmacology, Amsterdam, v. 26, p. 136-141, 2008

MONTEIRO, S. M.; ROCHA, E.; FONTAÍNHAS-FERNANDES, A.; SOUSA, M. Quantitative histopathology of Oreochromis niloticus gills after copper exposure. Journal of Fish Biology, Malden, v. 73, p. 1376-1392, 2008.

MONTEIRO, V.; CAVALCANTE, D. G. S. M.; VILÉLA, M. B. F. A.; SOFIA, S. H.; MARTINEZ, C. B. R. In vivo and in vitro exposures for the evaluation of the genotoxic effects of lead on the Neotropical fish Prochilodus lineatus. Aquatic Toxicology, Amsterdam, v. 104, p. 291-298, 2011. 
MURANLI, F. D. G.; GÜNER, U. Induction of micronuclei and nuclear abnormalities in erythrocytes of mosquito fish (Gambusia affinis) following exposure to the pyrethroid insecticide lambdacyhalothrin. Mutation Research, Amsterdam, v. 726, p. 104-108, 2011.

NAYAK, P. Aluminum: impacts and disease. Environmental Research, Montreal, v. 89, n. 2, p. 101-115, 2002.

OHE, T.; WATANABE, T.; WAKABAYASHI, K. Mutagens in surface waters: a review. Mutation Research, Amsterdam, v. 567, p. 109-149, 2004.

OLIVEIRA-MARTINS, C. R.; GRISOLIA, C. K. Toxicity and genotoxicity of wastewater from gasoline stations. Genetics and Molecular Biology, Ribeirão Preto, v. 32, n. 4, p. 853-856, 2009.

OMAR, W. A.; ZAGHLOUL, K. H.; ABDEL-KHALEK, A. A.; ABO-HEGAB, S. Genotoxic effects of metal pollution in two fish species, Oreochromis niloticus and Mugil cephalus, from highly degraded aquatic environments. Mutation Research, Amsterdam, v. 746, p. 7-14, 2012.

PACHECO, M.; SANTOS, M. A. Induction of liver EROD and erythrocytic nuclear abnormalities by cyclophosphamide and PAHs in Anguilla anguilla L. Ecotoxicology and Environmental Safety, Amsterdam, v. 40, p. 71-76, 1998.

PANDEY, S.; PARVEZ, S.; ANSARI, R. A.; ALI, M.; KAUR, M.; HAYAT, F.; AHMAD, F.; RAISUDDIN, S. Effects of exposure to multiple trace metals on biochemical, histological and ultrastructural features of gills of a freshwater fish, Channa punctatus Bloch. Chemico-Biological Interactions, Clare, v. 174, n. 3, p. 183-192, 2008.

PEREIRA, S.; PINTO, A. L.; CORTES, R.; FONTAÍNHASFERNANDES, A.; COIMBRA, A. M.; MONTEIRO, S. M. Gill histopathology and oxidative stress evaluation in native fish captured in Portuguese northwestern Rivers. Ecotoxicology and Environmental Safety, Amsterdam, v. 90, n. 1, p. 157-166, 2013.

POLEKSIC, V.; MITROVIC-TUTUNDZIC, V. Fish gills as a monitor of sublethal and chronic effects of pollution. In: MÜLLER, R.; LLOYD, R. (Ed.). Sublethal and chronic effects of pollutants on freshwater fish. Cambridge: Cambridge University Press, 1994. p. 339-352.
PÓLEO, A. B. S.; LYDERSEN, E.; MUNIZ, I. P. The influence of temperature on aqueous aluminum chemistry and survival of Atlantic salmon (Salmo salar L.) fingerlings. Aquatic Toxicology, Amsterdam, v. 21, p. 267-278, 1991.

SANTOS, D. C. M.; MATTA, S. L. P.; OLIVEIRA, J. A.; SANTOS, J. A. D. Histological alterations in gills of Astyanax aff. bimaculatus caused by acute exposition to zinc. Experimental and Toxicologic Pathology, Hannover, v. 64, p. 861-866, 2012.

SIRAJ BASHA, P.; USHA RANI, A. Cadmium-induced antioxidant defense mechanism in freshwater teleost Oreochromis mossambicus (Tilapia). Ecotoxicology and Environmental Safety, Amsterdam, v. 56, p. 218-221, 2003.

TALAPATRA, S. N.; BANERJEE, S. K. Detection of micronucleus and abnormal nucleus in erythrocytes from the gill and kidney of Labeo bata cultivated in sewage-fed fish farms. Food and Chemical Toxicology, Kidlington, v. 45, n. 2, p. 210-215, 2007.

TAKASHIMA, F.; HIBIYA, T. An atlas of fish histology. Normal and pathological features. Michigan: University of Michigan, 1995. $195 \mathrm{p}$.

UDROIU, I. The micronucleus test in piscine erythrocytes. Aquatic Toxicology, Amsterdam, v. 79, p. 201-204, 2006.

VOURINEN, P. J.; KEINÄNEN, M.; PEURANEN, S.; TIGERSTEDT, C. Reproduction, blood and plasma parameters in gill histology of vendance (Coregonus albula L.) in longterm exposure to acidity and aluminum. Ecotoxicology and Environmental Safety, Amsterdam, v. 54, p. 255-276, 2003.

VOURINEN, P. J.; VOURINEN, M. Effects of long-term prespawning acid/aluminum exposure on whitefish (Coregonus wartmanni) reproduction and blood and plasma parameters. Finish Fish Research, Helsinki, v. 12, p. 125-133, 1991.

VOURINEN, P. J.; VOURINEN, M.; PEURANEN, S. Long-term exposure of adult whitefish (Coregonus wartmanni) to low $\mathrm{pH} /$ aluminum: effects on reproduction, growth, blood composition and gills. In: KAUPPI, P.; ANTTILA, P.; KENTTÄMIES, K. (Ed.). Acidification in Finland. Berlin: Springer, 1990. P. 941-961.

YTRESTØYL, T.; FINSTAD, B.; MCKINLEY, R. S. Swimming performance and blood chemistry in Atlantic salmon spawners exposed to acid river water with elevated aluminium concentrations. Journal of Fish Biology, Malden, v. 58, p. 1025-1038, 2001. 